\title{
Initial Coronavirus Disease-2019 Closure Strategies Adopted by a Convenience Sample of US School Districts: Directions for Future Research
}

\author{
Jeff Schlegelmilch, MPH, MBA; Claire Douglas, BA
}

\section{ABSTRACT}

School closures are an important strategy to mitigate the impacts of a pandemic. But an optimal approach to transitioning from in-person to distance learning approaches is lacking. We analyzed a convenience sample of public K-12 schools in the early weeks of the COVID-19 pandemic in the United States. This initial snapshot provides some insights to inform future research into the variation of strategies across school districts, and would benefit from more rigorous methods to determine true correlations between demographic and geographic factors. Additionally, many of these strategies have evolved in response to ongoing and prolonged public health social distancing measures implemented after this analysis was conducted.

Key Words: COVID-19, infectious disease transmission, mitigation, pandemics, school closure

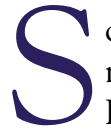
chool closures are an important strategy to mitigate the impacts of a pandemic. ${ }^{1,2}$ However, an optimal approach to transitioning from in-person to distance learning approaches is lacking. ${ }^{3}$ We analyzed a convenience sample of public K-12 schools in the early weeks of the coronavirus disease2019 (COVID-19) pandemic in the United States.

This analysis was conducted as a snapshot of strategies in place between March 16 and March 20, 2020, using a convenience sample of 9 school districts that were closed as part of social distancing strategies (Table 1). The sample was selected based on online availability of district closure and continuity of education plans. Efforts were made to achieve some geographic and socioeconomic diversity in the sample, although this is not exhaustive nor fully representative. Information was obtained from state and school district websites, EdData, the Centers for Disease Control and Prevention, and the National Community Survey, as well as media coverage closures.

The implementation of distance learning was extremely varied, although our initial analysis suggests some insights to explore further. Whether or not these constitute broader patterns warrants further research.

One approach treated the closures as a prolonged spring break, sending students home without supplemental education material or clear plans for transitioning to distance learning. This approach was observed in a small low-density, rural school district. This district had lower reported instances of COVID-19 at the time of implementation. Other school districts provided students with study packets, accessed either online or distributed/picked up at school. This approach was seen in low- to middle-income communities and less affluent suburban counties. Several school districts cited students' lack of access to reliable Internet and devices as a reason to use study packets instead of online instruction.

More affluent urban and suburban schools used online instruction platforms. Some used a blend of worksheets, online resources, and online instruction, while schools attempted to provide online-capable devices to students in need. Some broadcasted educational material through public access TV channels, social media, and on their websites, while arranging device distribution. Some were also working with Internet service providers to provide low- or no-cost Internet access. One district employed Wi-Fi-equipped school buses throughout the community for students to access.

The 1 constant across school districts was to continue to provide meals for students using free or reduced meal programs. The predominant strategy had students or parents picking up bagged food to take home, although some districts delivered bagged meals via regular school bus routes. 


\begin{tabular}{|c|c|c|c|c|c|}
\hline \multicolumn{6}{|l|}{ School Districts Analyzed } \\
\hline School District & Schools & Students & $\begin{array}{l}\text { Median Income } \\
\quad \text { (US \$) }\end{array}$ & $\begin{array}{l}\text { Student Poverty } \\
\text { Rate }\end{array}$ & $\begin{array}{l}\text { Initial Closure Strategy } \\
\text { (as of } 3 / 20 \text { ) }\end{array}$ \\
\hline $\begin{array}{l}\text { NYC Public Schools } \\
\text { New York, NY }\end{array}$ & 1800 & 1126501 & $\$ 57782$ & $73 \%$ & $\begin{array}{l}\text { Device-based distance learning, } \\
\text { effort to provide devices }\end{array}$ \\
\hline $\begin{array}{l}\text { Los Angeles Unified School } \\
\text { District } \\
\text { Los Angeles, CA }\end{array}$ & 1009 & 621414 & $\$ 68272$ & $80 \%$ & $\begin{array}{l}\text { Device- and free resource-- } \\
\text { based distance learning, effort } \\
\text { to provide devices and } \\
\text { broadband access }\end{array}$ \\
\hline $\begin{array}{l}\text { Montgomery County Public } \\
\text { Schools } \\
\text { Montgomery County, MD }\end{array}$ & 212 & 165267 & $\$ 103178$ & $34 \%$ & $\begin{array}{l}\text { Device-based distance learning, } \\
\text { utilities to provide free or } \\
\text { subsidized broadband }\end{array}$ \\
\hline $\begin{array}{l}\text { Baltimore City Public Schools } \\
\text { Baltimore, MD }\end{array}$ & 161 & 79187 & $\$ 46641$ & $50 \%$ & $\begin{array}{l}\text { Packet-based learning, limited } \\
\text { access to devices and } \\
\text { broadband }\end{array}$ \\
\hline $\begin{array}{l}\text { Seattle Public Schools } \\
\text { Seattle, WA }\end{array}$ & 104 & 53627 & $\$ 79565$ & $29 \%$ & $\begin{array}{l}\text { Packet- and free resource- } \\
\text { based learning, limited access } \\
\text { to devices and broadband }\end{array}$ \\
\hline $\begin{array}{l}\text { Pasco County Schools } \\
\text { Pasco County, FL }\end{array}$ & 96 & 75001 & $\$ 48289$ & $56 \%$ & $\begin{array}{l}\text { Device-based distance learning, } \\
\text { effort to provide devices and } \\
\text { broadband }\end{array}$ \\
\hline $\begin{array}{l}\text { Port Angeles School District } \\
\text { Port Angeles, WA }\end{array}$ & 8 & 3701 & $\$ 48002$ & - & $\begin{array}{l}\text { Extended spring break, no } \\
\text { instructional support }\end{array}$ \\
\hline $\begin{array}{l}\text { Hastings Area School District } \\
\text { Barry County, Ml }\end{array}$ & 6 & 2571 & $\$ 57312$ & $47 \%$ & $\begin{array}{l}\text { Packet-based learning, limited } \\
\text { access to devices and } \\
\text { broadband }\end{array}$ \\
\hline $\begin{array}{l}\text { Belleville Township High School } \\
\text { District } 201 \\
\text { Belville, IL }\end{array}$ & 3 & 4978 & $\$ 60301$ & $45 \%$ & $\begin{array}{l}\text { Device-based distance learning, } \\
\text { effort to provide devices and } \\
\text { broadband }\end{array}$ \\
\hline
\end{tabular}

This initial snapshot provides some insights to inform future research into the variation of strategies across school districts and would benefit from more rigorous methods to determine true correlations between demographic and geographic factors. Additionally, many of these strategies have evolved in response to ongoing and prolonged public health social distancing measures implemented after this analysis was conducted. Further evaluation of these strategies, their adaptations over time, and their impacts on students over a wider sample could provide important insights into strengthening educational distance learning strategies as part of broader public health disease control strategies in a pandemic.

\section{About the Authors}

National Center for Disaster Preparedness, The Earth Institute, Columbia University, New York (Mr Schlegelmilch, Ms Douglas) and School of International Public Affairs, Columbia University, New York (Ms Douglas).
Correspondence and reprint requests to Jeff Schlegelmilch, 475 Riverside Drive, Suite 401, New York, NY 10115 (e-mail: js4645@columbia.edu)

\section{Conflict of Interest Statement}

The authors have no conflicts of interest to declare.

\section{REFERENCES}

1. Qualls N, Levitt A, Kanade N, et al. Community mitigation guidelines to prevent pandemic influenza - United States, 2017. MMWR Recomm Rep. 2017;66(1):1.

2. Ebrahim SH, Ahmed QA, Gozzer E, et al. Covid-19 and community mitigation strategies in a pandemic. BMJ. 2020;368:m1066. Published March 17, 2020. https://www.bmj.com/content/368/bmj.m1066. Accessed April 5, 2020.

3. Uscher-Pines L, Schwartz HL, Ahmed F, et al. School practices to promote social distancing in K-12 schools: review of influenza pandemic policies and practices. BMC Public Health. 2018;18(1):406. 